\title{
VIRULENSI BEBERAPA ISOLAT METARHIZIUM ANISOPLIAE TERHADAP WALANG SANGIT (Leptocorisa oratorius F.) DI LABORATORIUM
}

\author{
Panji Perwira, Purnomo \& Solikhin \\ Jurusan Agroteknologi, Fakultas Pertanian Universitas Lampung \\ J1. Soemantri Bojonegoro No. 1 Bandar Lampung 35145 \\ Email: perwirapanji@yahoo.com
}

\begin{abstract}
ABSTRAK
Penelitian ini bertujuan untuk mempelajari pertumbuhan, viabilitas serta kerapatan dari beberapa isolat Metarhizium anisopliae dan mempelajari pengaruh aplikasi Metarhizium anisopliae terhadap mortalitas Leptocorisa oratorius F. Penelitian ini dilaksanakan di Laboratorium Hama Tumbuhan dan Laboratorium Penyakit Tumbuhan, Bidang Proteksi Tanaman Jurusan Agroteknologi, Fakultas Pertanian Universitas Lampung pada akhir tahun 2013 (Tahap I) dan dilanjutkan pada awal tahun 2015 (Tahap II). Hasil Penelitian menunjukkan bahwa : Tidak terdapat perbedaan viabilitas spora $M$. anisopliae yang nyata antar 5 isolat asal Tegineneng, Trimurjo, Gadingrejo, Bantul dan UGM; Kerapatan isolat asal UGM adalah 2,31 x 10 spora/ml, lebih tinggi dibandingkan dengan isolat asal Gadingrejo, Bantul, Tegineneng dan Trimurjo; Isolat M. anisopliae asal Tegineneng mampu membunuh walang sangit (Leptocorisa oratorius F.) hingga 44,67\%. Isolat lain memiliki kemampuan lebih rendah dibandingkan isolat asal Tegineneng.
\end{abstract}

Kata kunci: diameter koloni, kerapatan spora, Metarhizium anisoplia, viabilitas spora, virulensi, walang sangit (Leptocorisa oratorius $\mathrm{F}$.)

\section{PENDAHULUAN}

Padi (Oryza sativa L.) merupakan tanaman pangan yang sangat penting di dunia, melebihi kentang, jagung, gandum dan serealia lainnya. Tanaman ini dipertimbangkan sangat penting kehadirannya di dunia karena padi merupakan makanan pokok bagi lebih dari setengah penduduk dunia (Lu, 1999 dalam Maulidya, 2011).

Produksi padi di Indonesia pada tahun 2014 sebanyak 70,83 juta ton gabah kering giling (BPS, 2014). Namun, produksi tersebut kerap kali tak mampu memenuhi kebutuhan beras di dalam negeri. Oleh karena itu peningkatan produksi tanaman padi perlu terus dilakukaan, baik dengan perluasan lahan maupun dengan perbaikan cara budidaya tanaman. Seperti halnya tanaman lain, pembudidayaan tanaman padi tidak luput dari serangan hama dan penyakit. Salah satu serangga hama yang cukup penting pada tanaman padi adalah walang sangit (Leptocorisa oratorius F.).

Menurut Qomarodin (2006), pengendalian walang sangit oleh petani pada umumnya bertumpu pada penggunaan insektisida, tetapi hasilnya masih kurang memuaskan karena ternyata seringkali intensitas kerusakan tanaman padi yang diakibatkan oleh hama Leptocorisa oratorius $\mathrm{F}$. masih tetap tinggi. Terlebih lagi penggunaan insektisida yang luas dapat menyebabkan musnahnya musuh alami, hama menjadi resisten dan pencemaran terhadap lingkungan (Wisang, 1999).

Praktik pengendalian hayati dapat menggunakan predator, parasitoid, dan patogen serangga. Salah satu jenis cendawan entomopatogen yang digunakan sebagai agen hayati dan dapat menginfeksi beberapa jenis serangga, antara lain dari ordo Coleoptera, Lepidoptera, Homoptera, Hemiptera, dan Isoptera (Gabriel dan Riyanto, 1989). Penelitian ini bertujuan untuk mempelajari pertumbuhan, viabilitas serta kerapatan dari beberapa isolat Metarhizium anisopliae dan mempelajari pengaruh aplikasi Metarhizium anisopliae terhadap mortalitas Leptocorisa oratorius $\mathrm{F}$.

\section{BAHAN DAN METODE}

Penelitian ini dilaksanakan di Laboratorium Hama Tumbuhan dan Laboratorium Penyakit Tumbuhan, Bidang Proteksi Tanaman Jurusan Agroteknologi, Fakultas Pertanian Universitas Lampung pada akhir tahun 2013 (Tahap I) dan dilanjutkan pada awal tahun 2015 (Tahap II). Kemudian dilanjutkan pada bulan Maret 2015 hingga selesai.

Penelitian ini berupa percobaan dalam Rancangan Acak Kelompok (RAK) dengan pengujian virulensi terdiri dari 6 perlakuan dan 3 kelompok, uji diameter terdiri dari 5 perlakuan dan 4 kelompok, uji viabilitas dan kerapatan terdiri dari 5 perlakuan dan 3 kelompok. 
Isolat yang digunakan Metarhiziumn anisopliae yang berasal dari lima macam tempat (Tegineneng, Gading Rejo, UGM, Bantul, dan Trimurjo) dan 1 kontrol sebagai perlakuan. Terdiri dari 3 kelompok waktu aplikasi yang berbeda. Aplikasi terhadap Leptocorisa oratorius F. pada pengenceran $10^{-3} \mathrm{ml}^{-1}$.

Penyiapan Serangga Leptocorisa oratorius F. Serangga walang sangit dicoba untuk dikembangbiakan dalam tempat pemeliharaan berukuran $(2,5 \mathrm{~m} \times 2 \mathrm{~m})$ dan diberi pakan padi yang sudah masak susu secara rutin. Pengembangbiakan hama walang sangit ternyata tidak berhasil, selanjutnya dilakukan pengambilan nimfa walang sangit di lapangan. Nimfa berwarna hijau pucat, kemerahan serta memiliki antena berwarna keputihan yang lebih panjang dari tubuhnya. Panjang tubuh nimfa instar pertama sekitar $2 \mathrm{~mm}$, sedangkan nimfa instar terakhir dapat mencapai 13 sampai $14 \mathrm{~mm}$ (Kalshoven, 1981). Kemudian nimfa walang sangit dipelihara di tempat pemeliharaan yang sama dengan sebelumnya hingga mencapai tahap imago dan diberi pakan padi yang sudah masak susu secara rutin. Setelah nimfa sudah menjadi imago, kemudian dipindahkan ke kotak kurungan plastik transparan berukuran $1 \mathrm{~m} \times 0,5 \mathrm{~m}$ dengan bulir padi masak susu sebagai pakannya.

Pengujian Kerapatan konidia M. anisopliae. Biakan cendawan Metarhizium spp. pada masingmasing media diambil sebanyak 1 potongan bor gabus lalu ditambahkan ke dalam air steril dalam tabung reaksi steril berukuran $10 \mathrm{ml}$ dan dikocok dengan shaker hingga tercampur merata ( \pm 10 menit). Selanjutnya dilakukan pengenceran hingga $10^{-3}$. Kerapatan spora dihitung dengan menggunakan alat hemasitometer di bawah mikroskop binokuler dengan perbesaran 400 kali. Kerapatan spora dihitung dengan menggunakan rumus Gabriel \& Riyatno (1989) sebagai berikut:

$$
\mathrm{C}=\frac{\mathrm{t} \times \mathrm{d}}{\mathrm{n} \times 0,25} \times 10^{6}
$$

Keterangan:

$\mathrm{C}=$ kerapatan spora per ml larutan

$\mathrm{t}=$ jumlah total spora dalam kotak yang diamati

$\mathrm{d}=$ tingkat pengenceran

$\mathrm{n}=$ jumlah $\operatorname{kotak}(5$ kotak besar $\mathrm{x} 16$ kotak kecil $)$

Pengujian viabilitas Metarhizium anisopliae. Viabilitas spora cendawan Metarhizium spp. ditentukan setelah suspensi spora diinkubasikan selama 24 jam. Satu tetes suspensi tersebut diteteskan pada kaca preparat dan ditutup dengan gelas penutup dan diletakkan di bawah mikroskop dengan perbesaran 400 kali. Selanjutnya akan dihitung jumlah spora yang berkecambah dan tidak berkecambah pada luasan bidang pandang yang telah ditentukan. Penghitungan viabilitas spora dilakukan setiap 2 jam sekali mulai sejak 12 jam sampai dengan 24 jam setelah inkubasi. Viabilitas spora dihitung dengan menggunakan rumus Gabriel \& Riyatno (1989) sebagai berikut :

$$
\mathrm{V}=\frac{\mathrm{g}}{(\mathrm{g}+\mathrm{u})} \times 100 \%
$$

Keterangan :

$\mathrm{V}=$ persentase konidia yang berkecambah

$\mathrm{g}=$ rata-rata konidia yang berkecambah

$\mathrm{u}=$ rata-rata konidia yang tidak berkecambah

Pengujian Virulensi Entomopatogen. Spora yang diambil dari media diencerkan dengan air steril sampai $10^{-3} / \mathrm{ml}$, kemudian disemprotkan pada 20 ekor imago Leptocorisa oratorius F. Serangga hama kemudian dipindahkan ke tempat pemeliharaan yang dibuat dari gelas plastik bekas wadah air mineral dan diberi makan berupa bulir padi masak susu. Pengamatan serangga yang mati dilakukan pada 3, 7, dan 10 hari setelah aplikasi (HSA). Menurut Rustama et al. (2008) bahwa mortalitas serangga dapat dihitung menggunakan rumus seperti berikut :

$$
M=\frac{\sum \mathrm{n}}{\sum \mathrm{N}} \times 100 \%
$$

Keterangan :

$\mathrm{M}=$ mortalitas serangga $(\%)$

$\mathrm{n}$ = serangga yang mati (ekor)

$\mathrm{N}=$ jumlah serangga yang diuji (ekor)

Apabila kematian serangga walang sangit pada kontrol cukup tinggi, maka angka kematian serangga dikoreksi menggunakan rumus Abbot sebagai berikut:

$$
\mathrm{A} 1=\frac{\mathrm{A}-\mathrm{B}}{100-\mathrm{B}} \times 100 \%
$$

Keterangan :

A1 $=$ Kematian setelah koreksi $(\%)$

$\mathrm{A}=$ Kematian serangga uji (\%)

$\mathrm{B}=$ Kematian serangga kontrol

\section{HASIL DAN PEMBAHASAN}

Penelitian ini terdiri dari pengukuran pertumbuhan cendawan, kerapatan spora, viabilitas spora, dan virulensi cendawan Metarhizium anisopliae untuk mengetahui 
pengaruhnya terhadap mortalitas walang sangit (Leptocorisa oratorius F.).

Hasil Pengujian Pertumbuhan Cendawan. Hasil analisis ragam menunjukkan bahwa diameter koloni cendawan menunjukkan perbedaan ukuran diameter pada setiap pengamatan. Pertumbuhan $M$. anisopliae dari UGM pada 3 hari setelah inkubasi (hsi) mulai menunjukkan pertumbuhan koloni yang paling tinggi dibandingkan dengan isolat lainnya dengan rata-rata diameter mencapai $2,79 \mathrm{~cm}$. Kemudian pada 5 hari setelah inkubasi (hsi) isolat Gadingrejo mulai menunjukkan tingkat pertumbuhan tertinggi yaitu mencapai 8,03 cm dan pada 7 hari setelah inkubasi (hsi) dengan hasil rata-rata diameter mencapai $8,38 \mathrm{~cm}$. Isolat Gadingrejo menunjukkan hasil yang paling tinggi tingkat pertumbuhannya dibandingkan dengan isolat yang lainnya (Tabel 1).

Hasil Pengujian Tingkat Kerapatan. Hasil penelitian terhadap pengujian kerapatan spora $M$. anisopliae menunjukkan hasil yang berbeda nyata antara masing-masing perlakuan (Tabel 2). Dari (Tabel 2) terlihat bahwa kerapatan spora yang memiliki tingkat kerapatan tertinggi adalah isolat yang berasal dari UGM dengan hasil rata-rata 2,31 spora/ml lebih tinggi dibandingkan dengan isolat asal Gadingrejo dengan hasil rata-rata $1,65 \mathrm{spora} / \mathrm{ml}$.

Hasil Pengujian Viabilitas Spora. Hasil penelitian terhadap pengujian viabilitas spora $M$. anisopliae menunjukkan hasil yang tidak berbeda nyata antara masing-masing perlakuan (Tabel 3). Viabilitas spora yang memiliki tingkat perkecambahan tertinggi berdasarkan rata - rata adalah isolat yang berasal dari UGM dengan hasil 79,91\% kemudian diikuti dari isolat yang berasal dari Gadingrejo 55,22\%, Tegineneng dengan hasil 45,27 $\%$, diikuti Bantul 42,28 \% , dan Trimurjo 26,46\%.

Hasil Pengujian Virulensi M. Anisopliae. Pengujian virulensi isolat $M$. anisopliae memiliki hasil mortalitas yang beragam, akan tetapi tidak berbeda nyata antar perlakuan setelah dilakukan analisis statistik. Berdasarkan rata-rata persentase mortalitas serangga, isolat yang memiliki tingkat virulensi yang relatif lebih tinggi dari yang lainnya adalah isolat dari Tegineneng dengan hasil mencapai $44,67 \%$ serangga mati (Tabel 4).

Pada pengujian virulensi beberapa isolat $M$. anisopliae setelah 10 hari penginfeksian menghasilkan mortalitas $L$. oratorius $F$. tertinggi dengan nilai mencapai $44,67 \%$ serangga yang mati, yaitu terdapat pada isolat

Tabel 1. Rata-rata diameter pertumbuhan koloni cendawan M. anisopliae $(\mathrm{cm})$.

\begin{tabular}{lccc}
\hline \multirow{2}{*}{ Asal Isolat } & \multicolumn{3}{c}{ Diameter Koloni Cendawan M. anisopliae $(\mathrm{cm})$} \\
\cline { 2 - 4 } & $3 \mathrm{hsi}$ & $5 \mathrm{hsi}$ & $7 \mathrm{hsi}$ \\
\hline Trimurjo & $1,53 \mathrm{tn}$ & $4,95 \mathrm{~d}$ & $7,91 \mathrm{tn}$ \\
Gadingrejo & $1,42 \mathrm{tn}$ & $8,03 \mathrm{a}$ & $8,38 \mathrm{tn}$ \\
Bantul & $2,35 \mathrm{tn}$ & $5,02 \mathrm{c}$ & $6,49 \mathrm{tn}$ \\
Tegineneng & $1,14 \mathrm{tn}$ & $3,66 \mathrm{e}$ & $5,84 \mathrm{tn}$ \\
UGM & $2,79 \mathrm{tn}$ & $6,22 \mathrm{~b}$ & $7,47 \mathrm{tn}$ \\
\hline
\end{tabular}

Keterangan: hsi $=$ hari setelah inokulasi, tn $=$ tidak nyata (data dibandingkan secara vertikal)

Tabel 2. Pengujian tingkat kerapatan spora $M$. anisopliae (nilai tengah yang diikuti huruf yang sama tidak berbeda nyata menurut uji BNT pada taraf $(5 \%)$ dengan nilai 0,01 .

\begin{tabular}{|c|c|}
\hline Asal Isolat & Nilai Tengah Kerapatan Spora (Spora/ml) \\
\hline UGM & $2,31 \times 10^{9} \mathrm{a}$ \\
\hline Trimurjo & $2,05 \times 10^{9} \mathrm{~b}$ \\
\hline Bantul & $2,01 \times 10^{9} \mathrm{c}$ \\
\hline Tegineneng & $1,75 \times 10^{9} \mathrm{~d}$ \\
\hline Gadingrejo & $1,65 \times 10^{9} \mathrm{e}$ \\
\hline Nilai & BNT: 0,01 \\
\hline
\end{tabular}


Tabel 3. Tabel rata - rata viabilitas spora M. anisopliae $(\%)$.

\begin{tabular}{lcc}
\hline Asal Isolat & Rataan (\%) & Transformasi \\
\hline Trimurjo & 26,46 & $2,03 \mathrm{tn}$ \\
Tegineneng & 45,27 & $2,65 \mathrm{tn}$ \\
Bantul & 42,28 & $2,60 \mathrm{tn}$ \\
Gadingrejo & 55,22 & $2,39 \mathrm{tn}$ \\
UGM & 76,91 & $2,88 \mathrm{tn}$ \\
\hline
\end{tabular}

Keterangan: $\mathrm{tn}=$ tidak berbeda nyata pada taraf 5 . Data ditransformasikan menggunakan log 10

Tabel 4. Mortalitas L. oratorius (\%) pada 10 hari setelah aplikasi.

\begin{tabular}{ll}
\hline \multicolumn{1}{c}{ Asal Isolat } & Rataan $(\%)$ \\
\hline Tegineneng & $44,67 \mathrm{a}$ \\
Gadingrejo & $20,67 \mathrm{~b}$ \\
Bantul & $17,67 \mathrm{~b}$ \\
UGM & $14,00 \mathrm{c}$ \\
Trimurjo & $12,33 \mathrm{c}$ \\
Kontrol & $0,00 \mathrm{~d}$ \\
\hline
\end{tabular}

Keterangan: Nilai pada kolom yang diikuti dengan huruf yang sama tidak berbeda nyata menurut uji BNT 5\%

asal Tegineneng, kemudian diikuti isolat dari Gadingrejo dengan nilai 20,67 \% dan isolat asal Bantul dengan nilai $17,67 \%$ serangga mati. Dalam aplikasi terhadap $L$. oratorius F. pada penelitian ini, suspensi $M$. anisopliae menggunakan pengenceran yang sama yaitu $10^{-3} / \mathrm{ml}$ setiap perlakuan dan aplikasi dilakukan hanya satu kali. Akan tetapi semua persentase hasil mortalitas tidak berbeda nyata setelah dianalisis statistik pada uji BNT dengan taraf nyata $5 \%$.

Hal ini tidak jauh berbeda dengan penelitian Efenndy (2010), bahwa mortalitas Wereng Batang Coklat (Nilavarpata lugens) tertinggi mencapai 55\% oleh M. anisopliae mungkin karena aplikasi dilakukan hanya satu kali, dapat disebabkan karena nimfa wereng batang coklat mengalami ganti kulit, sehingga konidia yang telah menempel pada kulit ikut terlepas, juga dapat disebabkan memang karena viabilitas konidia cukup rendah (paling tinggi 65,1\%). Begitupun dengan hasil penelitian (Prayogo dan Tengkano 2004) yang menyatakan bahwa mortalitas $S$. litura juga sangat ditentukan oleh frekuensi aplikasi $M$. anisopliae.
Aplikasi $M$. anisopliae satu kali sebenarnya sudah mampu mematikan S. litura hingga $40 \%$.

Secara regresi penelitian ini menunjukkan bahwa tingkat virulensi cendawan $M$. anisopliae tidak dipengaruhi oleh tingkat pertumbuhan diameter cendawan, viabilitas cendawan dan kerapatan cendawan. Grafik regresi pengukuran diameter cendawan M. anisopliae dari Gadingrejo (Gambar 1) memiliki tingkat pertumbuhan tertinggi yaitu $8,38 \mathrm{~cm}$ namun memiliki persentase mortalitas $L$. oratorius hanya $48 \%$. Di sisi lain isolat asal Tegineneng memiliki nilai pertumbuhan isolat terkecil yaitu sebesar $5,64 \mathrm{~cm}$ namun memiliki mortalitas $L$. oratorius dengan angka persentase terbesar yaitu $63 \%$.

Grafik regresi viabilitas spora dengan mortalitas (Gambar 2) didapatkan hasil yang tidak berbeda nyata antara viabilitas dengan mortalitas. Hal ini terjadi karena mungkin penambahan bahan pembawa yaitu media SDA menyebabkan viabilitas konidia M. anisopliae dapat bertahan. Begitupun pada grafik regresi kerapatan spora dengan mortalitas (Gambar 3) menunjukkan hasil yang tidak berbeda nyata. Hal ini dikarenakan pada pengamatan kerapatan spora tidak menggunakan bahan pembawa. Menurut Effendy (2010) bioinsektisida tanpa bahan pembawa kerapatan konidianya $8,3 \times 10^{6}$ konidia/ $\mathrm{ml}$ berbeda nyata dengan bioinsektisida yang menggunakan bahan pembawa. Hal ini dapat disebabkan bahan pembawa bioinsektisida waktu pengenceran yang diambil 5 gram bersama bahan pembawa, sedangkan konidia tanpa bahan pembawa diambil 5 gram hanya konidia saja. Hal ini akan mengakibatkan jumlah konidia dalam suspensi memang sudah berbeda, tentunya konidia tanpa bahan pembawa akan lebih banyak. Namun belum tentu kerapatan yang tinggi dapat mematikan serangga, dalam penelitian ini angka kerapatan tertinggi dicapai oleh UGM yaitu $2,31 \times 10^{9} \mathrm{spora} / \mathrm{ml}$ namun angka mortalitas hanya $14 \%$ artinya kemampuan spora isolat asal UGM tidak mampu menempel dan berkecambah dengan baik. Kemampuan konidia untuk berkecambah sangat penting untuk melakukan penetrasi pada inang dan sangat tergantung pada faktor lingkungan.

Dalam pengujian tingkat pertumbuhan cendawan dan viabilitas spora, menggunakan media yang berbeda dengan pengujian virulensi, yaitu media SDA (Sabouraud Dextrose Agar). Media SDA (Sabouraud Dextrose Agar)merupakan salah satu media pertumbuhan yang digunakan untuk pertumbuhan cendawan yang sengaja dibuat untuk memiliki kandungan nutrisi untuk mensuplai makanan terhadap cendawan. Komposisi dari media SDA (Sabouraud Dextrose Agar) yang digunakan adalah $40 \mathrm{~g}$ Dextrose, $5 \mathrm{~g}$ Pepton, $5 \mathrm{~g}$ kasein, $15 \mathrm{~g}$ agar dan 1 liter air destilata. Glukosa 


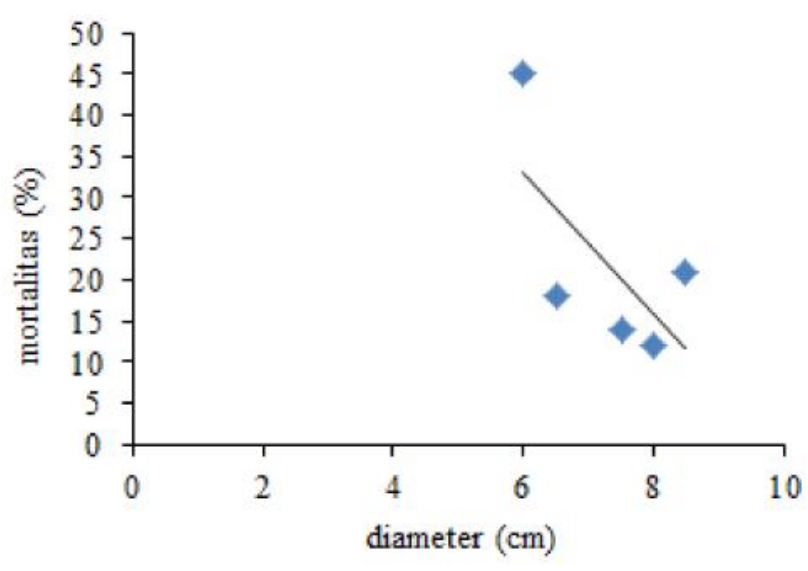

Gambar 1. Grafik regresi antara diameter dan mortalitas L. oratorius. $\mathrm{y}=-8,879 \mathrm{x}+85,79, \mathrm{R}^{2}=0,493$.

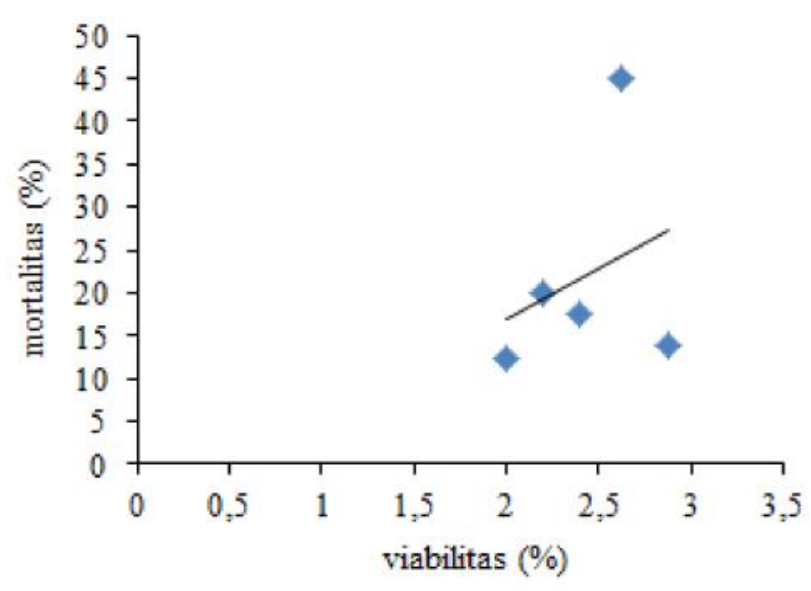

Gambar 2. Grafik regresi antara viabilitas spora dan mortalitas L. oratorius. Persamaan y $=$ $11,29 \mathrm{x}-6,489 . \mathrm{R}^{2}=0,075$.

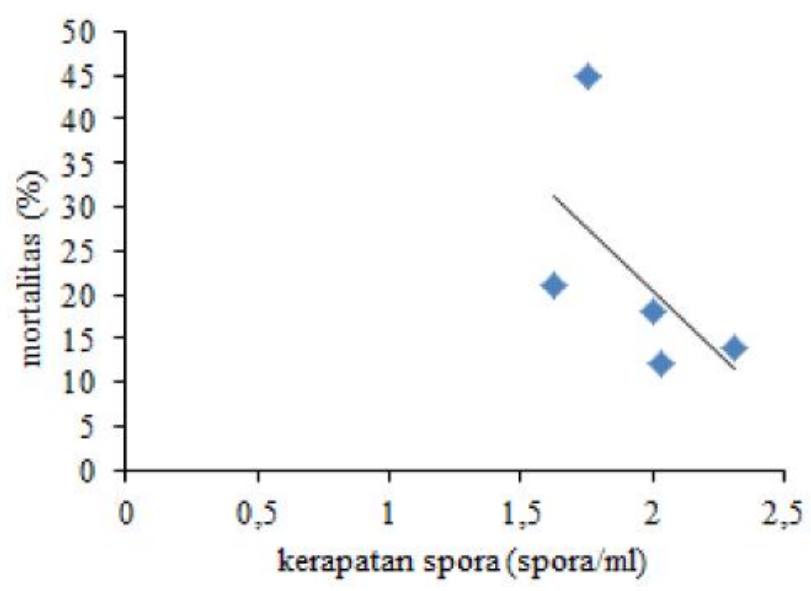

Gambar 3. Grafik regresi antara kerapatan spora dan mortalitas L. oratorius. $\mathrm{y}=-30,16 \mathrm{x}+80,81$. $\mathrm{R}^{2}=0,359$. merupakan salah satu jenis monosakarida yang menjadi sumber energi dan sebagai media pertumbuhan cendawan Candida albicans dalam sistem metabolisme. Monosakarida merupakan gula sederhana penyusun karbohidrat yang tidak dapat diuraikan secara hidrolisis. Bentuk alami (D-glukosa) dapat disebut juga dengan dekstrosa. Glukosa berperan sebagai sumber karbon bagi pertumbuhan cendawan Candida albicans (Lestari, 2012 dalam Wayan et al., 2014). Sedangkan pengujian virulensi menggunakan media serangga $L$. oratorius yang berarti akan menjadi berbeda nutrisi yang akan diserap bahkan bisa jadi nutrisi yang tekandung dalam serangga uji terbatas sehingga menyebabkan hasil yang tidak sesuai.

Berdasarkan rata-rata persentase mortalitas serangga, isolat yang memiliki tingkat virulensi yang relatif lebih tinggi dari yang lainnya adalah isolat dari Tegineneng dengan hasil mencapai 63,33\% serangga mati. Isolat M. anisopliae asal Tegineneng relatif lebih baik berdasarkan perhitungan rata-rata untuk digunakan sebagai agens pengendali hayati hama walang sangit (Leptocorisa oratorius F.). Pada penelitian Furqan (2011), isolat asal Tegineneng juga memiliki kemampuan virulensi yang cukup baik juga yaitu sebesar 76,25\% berdasarkan nilai rata-rata dalam kasus hama kepik pengisap buah kakao (Helopeltis theivora).

Pada umumnya virulensi yang tinggi disebabkan oleh toksin yang terkandung dalam cendawan. Isolat $M$. anisopliae asal Tegineneng memiliki toksisitas yang tinggi untuk mematikan serangga $L$. oratorius sehingga mortalitasnya besar. Artinya dalam penelitian ini toksisitas dari masing-masing asal isolat $M$. anisopliae berbeda. Toksin menyebabkan terjadinya lisis pada integumen serangga yang tersusun dari protein dan khitin (Prayogo et al., 2005).

\section{KESIMPULAN}

Kesimpulan yang dapat diambil pada penelitian ini adalah pengujian viabilitas tidak terdapat hasil yang berbeda nyata antar 5 isolat asal Tegineneng, Trimurjo, Gadingrejo, Bantul dan UGM. Pengujian tingkat kerapatan pada isolat asal UGM dengan hasil rata-rata $2,31 \times 10^{9} \mathrm{spora} / \mathrm{ml}$ paling tinggi dibandingkan dengan isolat asal Gadingrejo, Bantul, Tegineneng dan Trimurjo. Isolat M. anisopliae asal Tegineneng mampu membunuh walang sangit (Leptocorisa oratorius $\mathrm{L}$.) hingga 44,67\%. Isolat lain memiliki kemampuan lebih rendah dibanding isolat asal Tegineneng. 


\section{DAFTAR PUSTAKA}

Badan Pusat Statistik. 2014. Produksi dan produktivitas tanaman pangan. Available online at http:// www.bps.go.id., [3 Agustus 2015].

Effendy, T.A., S. Robby, S. Abdullah, dan M. Abdul. 2010. Jamur Entomopatogen Asal Tanah Lebak di Sumatera Selatan dan Potensinya Sebagai Agensia Hayati Walang Sangit (Leptocorisa Oratorius F.). Jurnal HPT Tropika. 10 (2): 154-161.

Furqon, M. 2012. Virulensi Beberapa Isolat Metarhizium anisopliae Terhadap Mortalitas Kepik Penghisap Buah Kakao (Helopeltis Spp.). Skripsi. Universitas Lampung. Bandar Lampung.

Maulidya, N. 2011. Pengujian Vigor Daya Simpan dengan Metode Pengusangan Cepat Kimia serta Pengujian Vigor Kekuatan Tumbuh pada Benih Padi (Oryza sativa L.). Skripsi. Institut Pertanian Bogor. Bogor.

Prayogo, Y., W. Tengkano, dan Marwoto. 2005. Prospek Cendawan Entomopatogen Metarhizium anisopliae untuk Mengendalikan Ulat Grayak Spodoptera litura pada Kedelai. J. Litbang Pertanian. 24(1): 19 - 26.
Purnomo, H. 2010. Pengantar Pengendalian Hayati. CV. Andi Offset. Yogyakarta.

Riana, D. 2000. Biologi Hama Tanaman Kelapa Sawit (Elaeis guineensis Jacq.) Tirathaba mundella Wlk. (Lepidoptera: Pyralidae) serta Uji Beberapa Konsenterasi Cendawan Beauveria bassiana (Balsamo) Vuillemin dan Metarhizium anisopliae (Metschnikoff) Sorokin dalam Pengendaliannya. Skripsi. Institut Pertanian Bogor. Bogor.

Qomarodin. 2006. Pengendalian Walang Sangit (Leptocorisa oratorius F.) Ramah lingkungan di Tingkat Petani di Lahan Rawa Lebak. Temu Teknis Nasional Tenaga Fungsional Pertanian 2006, hlm: 377-380.

Wayan, I. G., B. R. W. Ida, dan Luh A. W. 2014. Pengaruh Penambahan Glukosa dan Waktu Inkubasi pada Media SDA (Sabaroud Dextrose Agar) terhadap Pertumbuhan Jamur Candida Albicans. Media Bina Ilmiah. 8(1): 51 - 56.

Wisang, B. L. 1999. Pembiakan Parasitoid Telur Gryon nixoni Mas. (Hymenoptera: Scelionidae) pada Inang Riptorus linearis $F$. dan Leptocorisa oratorius T. Skripsi. Institut Pertanian Bogor. Bogor. 